\title{
Evaluation of legal capacity by doctors and lawyers: the need for collaborative assessment
}

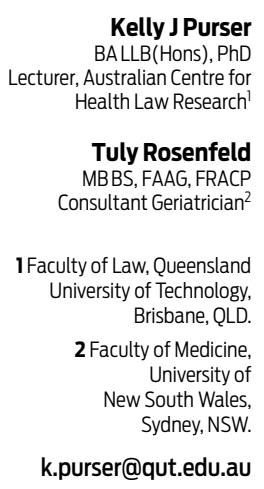

doi: 10.5694/mjal3.11191 egal and medical professionals are increasingly being asked to assess the capacity of individuals to make wills (an individual's testamentary capacity), enduring powers of attorney (EPAs) and advance health directives (AHDs), as well as other legal instruments. Australian society is ageing and consequently the number, as well as the complexity, of assessments being conducted is increasing.

A range of medical conditions may interfere with, or eliminate, a person's legal capacity to execute a will, EPA or AHD. Collaboration between legal and medical professionals in the assessment process is therefore particularly important. Miscommunication and misunderstanding occur between legal and medical professionals about the roles and responsibilities of each when conducting such assessments - is it legal or medical capacity being assessed $?^{1}$ - which can be exacerbated by inadequate professional education. Given that loss of legal capacity has significant consequences, assessment needs to be consistent and transparent. Currently, no nationally recognised system for this process exists in Australia. ${ }^{2}$ At the moment, there is an unsatisfactory, ad hoc implementation of various methods tailored to suit individual practitioners, be they legal or medical. This is legally, medically and ethically concerning. ${ }^{3}$

This article considers the challenges in assessing testamentary and decision-making capacity. While flexible assessment processes are clearly needed, there also needs to be consensus over clear and consistent principles and guidelines from which to begin. We suggest how a bestpractice approach can be made. For the purposes of this article, mental capacity is the general ability to understand the purpose, aim, significance and consequences of entering into particular transactions; and legal capacity is a person's ability to enter into such a transaction, or having a particular legally recognised status.

\section{The current assessment environment}

Advances in the medical understanding of the range of patterns of cognitive dysfunction in different types of dementia have made assessing testamentary capacity more complex. ${ }^{4}$ The growing need for assessments, and the anecdotally reported fear of litigation if assessments are not satisfactorily conducted, requires a re-evaluation of existing assessment paradigms.

The jurisdictional medley of state and territory legislative and common law provisions for substitute decision

\section{Summary}

Balancing the interests of individual autonomy and protection is an escalating challenge confronting an ageing Australian society.

One way this is manifested is in the current ad hoc and unsatisfactory way that capacity is assessed in the context of wills, enduring powers of attorney and advance health directives.

The absence of nationally accepted assessment guidelines results in terminological and methodological miscommunication and misunderstanding between legal and medical professionals.

Expectations between legal and medical professionals can be clarified to provide satisfactory capacity assessments based on the development of a sound assessment paradigm.

making also exacerbates an already challenging situation. This results in different provisions, either legislative and/or common law, applying in different jurisdictions throughout Australia. New South Wales, ${ }^{5}$ Queensland, ${ }^{6}$ Victoria $^{7}$ and the federal government ${ }^{8}$ have all conducted reviews in the past 5 years. AHDs have also been the subject of recent interest. ${ }^{9,10}$ However, no review has suggested or developed national capacity assessment guidelines.

\section{Addressing the challenges of capacity} assessment

Legal professionals are not trained to assess the effect of medical conditions, such as different types of dementia, on legal capacity. Medical professionals are not trained to assess the notion of legal capacity. Despite the disconnect from each other as a result, the professions together possess the skills necessary to satisfactorily assess capacity. We offer some suggestions to address the challenges of capacity assessment.

\section{General proposals for a collaborative process}

Legal and medical professionals should know what is being assessed, how and by whom. To further this end, clear communication is fundamental. ${ }^{11}$ In addition, legal and medical professionals need more continuing professional education, ${ }^{12}$ conducted within and between the professions.

A lack of terminological clarity and communication has made unclear the proper assignment of roles to legal and medical professionals and has increased the lack of 
clarity of process. There has been discussion regarding the separation of capacity as a medical, and competency as a legal, construct; however, it is unlikely that such an attempted separation would have any practical effect. ${ }^{13}$ Nevertheless, definitional clarity is needed and clear labelling of terms should be given - for example, legal competency or capacity and medical competency or capacity.

\section{Requesting a medical assessment of capacity}

A legal professional should first carefully consider whether medical assessment is necessary, recognising that a decision to seek it could concede that capacity is an issue if a third party contests the validity of a testamentary or enduring document. Assessments can also be undertaken to anticipate future legal proceedings that may question the individual's capacity.

Members of the legal profession should be responsible for providing to medical professionals situationspecific information about a person's legal capacity to be assessed. ${ }^{14}$ The issue of obtaining consent from a person to assess their capacity when they potentially lack the capacity to do so is also of fundamental importance but is outside the scope of this article.

Assessment should consider the individual's ability to understand, appreciate and communicate the reasons for his or her choices. ${ }^{15}$ Adequate assessment involves weighing the individual's ability to receive, understand, retain and recall relevant information; select between options for a course of action; understand the reasons for a decision; apply any information received to the circumstances; evaluate the benefits and risks of the choice; communicate the choice; and then persevere with that choice, at least until the decision is acted on. ${ }^{16}$ This will take into account the individual's specific circumstances, including any relevant medical factors, as well as social and cultural factors. ${ }^{17}$

\section{A three-stage process of assessment}

Ideally, there will be three stages of investigation. First, an initial assessment should be undertaken by a legal professional. Second, clinical assessment by a medical professional should be undertaken (if necessary). Third, there should be a final determination of whether the individual has legal capacity for the specific task in question.

In this process, it is fundamental to acknowledge that capacity is task- and time-specific in nature. Thought must also be given to the clinical models available for assessment and the benefits and disadvantages of the model(s) being considered, for example, the limitations of the Mini-Mental State Examination. ${ }^{18}$ It is also necessary to consider what has triggered questions about an individual's capacity. ${ }^{19}$ Care must be taken to avoid setting the bar too high in assessing competency or legal capacity because there is a risk of finding people incompetent who actually do have the capacity necessary at law to undertake the specific task.

Consideration must also be given to who should assess capacity. ${ }^{20}$ A legal professional can proceed without medical input when there is no or little evidence of diminished legal capacity. If there are mild problems, but their magnitude is insufficient to conclude that the individual cannot make decisions commensurate with adequate legal capacity, the legal professional can proceed but should consider seeking a medical opinion. If there is more pronounced evidence of diminished capacity, the legal professional should proceed cautiously, consulting with an appropriate medical professional. ${ }^{19}$ Formal medical capacity assessment should be undertaken if the individual clearly lacks legal capacity. ${ }^{19}$

\section{Requests for medical assessment of capacity}

Whenever medical assessment is sought, the referral letter from the lawyer should contain information about the individual's background, values and preferences, and reasons for contacting the lawyer; the legal capacity being assessed; and any known medical, social or environmental factors affecting capacity. ${ }^{19,20}$ Medical professionals should feel comfortable in refusing to assess capacity unless there is adequate information. ${ }^{20}$ The legal and medical professionals involved should discuss whether a written medical report is necessary, whether it would be useful, and what format it should take. ${ }^{19}$ Consent from the individual in question is imperative before any assessment can occur. ${ }^{20}$ The expense and disruption for an individual of seeking a medical assessment should also be considered. ${ }^{19}$

Information gathering by the lawyer or doctor, such as speaking to family members and friends, may also occur. Any circumstances discovered in this process that potentially affect the individual's capacity, ${ }^{20}$ such as "stress, grief, depression, reversible medical conditions, hearing or vision loss, or educational, socio-economic, or cultural background",19 also need to be considered and recorded in the assessment. Building trust with the individual, educating him or her about the process, accommodating any sensory (including hearing) impediments, and accommodating cultural and linguistic differences contribute importantly to a more accurate picture of that person's capacity and should be taken into account. ${ }^{19,20}$ The recording of the assessment process is important, through extensive file notes and perhaps video recording.

While national Australian guidelines are lacking, there are invaluable resources, such as the NSW Attorney General's Capacity Toolkit ${ }^{21}$ and the six-step capacityassessment model. ${ }^{16}$ The handbooks prepared for lawyers, ${ }^{19}$ judges ${ }^{22}$ and psychologists ${ }^{18}$ by the American Bar Association Commission on Law and Aging and the American Psychological Association are also potentially useful. Similarly, the British Medical Association and the Law Society have produced a guide for legal and medical professionals. ${ }^{20}$

\section{Assessing testamentary capacity}

The existence of testamentary capacity is a legal decision. Contemporaneous determinations during the life of a testator (the person making a will) are preferable to retrospective assessments after the testator's death, which are practically and evidentially problematic.

When assessing specific testamentary capacities, reference must be made to the principles established in the 1870 case of Banks $v$ Goodfellow, ${ }^{23}$ which sets out that 
the testator should understand the nature and effect of making a will, have an appreciation of the people who are natural beneficiaries, and understand the obligation to provide for people who are dependent on him or her. ${ }^{20}$ The testator should realise the effects and consequences of the testamentary provision that he or she is making. ${ }^{20}$ However, an assessment should go further than merely regurgitating the elements established in Banks. Legal professionals have a responsibility to ensure that medical professionals have adequate information to be able to report on an assessment of an individual's testamentary capacity. A medical professional should request further information if uncertain.

\section{Assessing decision-making capacity}

The legal tests for determining decision-making capacity differ from those for testamentary capacity, especially for EPAs, which require a higher standard. For EPAs, the concept of understanding should also include that the individual comprehends the powers to be given and can state or restrict those powers; the time at which the power given under the enduring document commences; that once the power comes into effect, the attorney will be able to use and have full authority over the powers given; that the individual may revoke the enduring power of attorney at any time, provided he or she is capable of doing so; ${ }^{24}$ and that an enduring power of attorney continues despite the individual losing capacity and being unable to oversee the attorney or revoke the power. There is currently no accepted clinical model to assess financial capacity.

\section{Professional liability considerations}

With testamentary and decision-making capacity assessment becoming more complex, it is possible that a practitioner's liability and the assessment process itself may be subject to increasing scrutiny, as will any attendant ethical issues. Careful assessment protocols can assist in obviating questions of professional liability. ${ }^{19}$

\section{Conclusion}

There is an increasing acknowledgement of the need for, and movement towards, an interdisciplinary approach to assessing legal capacity in the context of wills, EPAs and AHDs. A focused education campaign among the medical and legal professions, as well as in the general community, will be necessary, and national systems need to be developed. In the absence of these, to satisfactorily assess testamentary and decision-making capacity, medical professionals must be aware of the relevant legal tests that require clearer understanding of the expectations each profession has of the other. It is only through an interdisciplinary approach that satisfactory assessments of capacity in testamentary and decision-making contexts will occur.

Competing interests: No relevant disclosures.

Provenance: Not commissioned; externally peer reviewed.
1 Squires B, Barr F. The development of advance care directives in New South Wales. Australas J Ageing 2005; 24 (1 Suppl): S30-S35. doi: 10.1111/j.1741-6 612.2005.00097.x.

2 Carney T. Judging the competence of older people: an alternative? Ageing Soc 1995; 15: 515-534. doi: 10.1017/S0144686X00002889.

3 Aw D, Hayhoe B, Smajdor A, et al. Advance care planning and the older patient. QJM 2012; 105: 225-230.

4 Peisah C. Reflections on changes in defining testamentary capacity. Int Psychogeriatr 2005; 17: 709-712.

5 Standing Committee on Social Issues. Substitute decision-making for people lacking capacity. Final report; no. 43. Sydney: New South Wales Parliament, 2010. http://www.parliament.nsw.gov.au/prod/ parlment/committee.nsf/0/e00602d3c8f39ca5ca2576d500184231/\$FI LE/100225\%20SDM\%20Final\%20Report.pdf (accessed Jul 2014).

6 Queensland Law Reform Commission. A review of Queensland's guardianship laws. Report no. 67, Volumes 1-4. Brisbane: QLRC, 2010.

7 Law Reform Committee. Inquiry into powers of attorney. Final report. Melbourne: Parliament of Victoria, 2010. http://www.parliament.vic.gov. au/lawreform/article/1124 (accessed Jul 2014).

8 Standing Committee on Legal and Constitutional Affairs. Older people and the law. Canberra: Parliament of the Commonwealth of Australia, 2007. http://www.aph.gov.au/parliamentary_business/committees/ house_of_representatives_committees?url=/laca/olderpeople/report.htm (accessed Jul 2014).

9 Clinical, Technical and Ethical Principal Committee of the Australian Health Ministers' Advisory Council. A national framework for advance care directives. Canberra: AHMAC, 2011.

10 Clinical, Technical and Ethical Principal Committee of the Australian Health Ministers' Advisory Council. A national framework for advance care directives consultation draft. Canberra: AHMAC, 2010.

11 Collier B, Coyne C, Sullivan K, editors. Mental capacity: power of attorney and advance health directives. Sydney: Federation Press, 2005.

12 Parker M, Cartwright C. Mental capacity in medical practice and advance care planning: clinical, ethical and legal issues. In: Collier B, Coyne C, Sullivan K, editors. Mental capacity: power of attorney and advance health directives. Sydney: Federation Press, 2005.

13 Kershaw MM, Webber LS. Dimensions of financial competence. Psychiatr Psychol Law 2004; 11: 338-349. doi: 10.1375/pplt.2004.11.2.338.

14 Cockerill J, Collier B, Maxwell K. Legal requirements and current practices. In: Collier B, Coyne C, Sullivan K, editors. Mental capacity: power of attorney and advance health directives. Sydney: Federation Press, 2005.

15 Capacity Assessment Office, Ontario Ministry of the Attorney General. Guidelines for conducting assessments of capacity. Ottawa, Canada: Ministry of the Attorney General, 2005. http://www.attorneygeneral. jus.gov.on.ca/english/family/pgt/capacity/2005-06/guide-0505.pdf (accessed Jul 2014).

16 Darzinš P, William Molloy D, Strang D. Who can decide? The six step capacity assessment process. Adelaide: Memory Australia Press, 2000.

17 Pinsker DM, Pachana NA, Wilson J, et al. Financial capacity in older adults: a review of clinical assessment approaches and considerations. Clin Gerontol 2010; 33: 332-346. doi: 10.1080/07317115.2010.502107.

18 American Bar Association Commission on Law and Aging, American Psychological Association. Assessment of older adults with diminished capacity: a handbook for psychologists. Washington, DC: ABA and AMA, 2008. http://www.apa.org/pi/aging/programs/assessment/capacitypsychologist-handbook.pdf (accessed Jul 2014).

19 American Bar Association Commission on Law and Aging, American Psychological Association. Assessment of older adults with diminished capacity: a handbook for lawyers. Washington, DC: ABA and APA, 2005. https://www.apa.org/pi/aging/resources/guides/diminished-capacity.pdf (accessed Jul 2014).

20 British Medical Association, Law Society. Assessment of mental capacity: a practical guide for doctors and lawyers. 3rd ed. London: Law Society Publishing, 2011.

21 New South Wales Government Attorney General's Department. Capacity Toolkit. Sydney: State of NSW, 2008. http://www.diversityservices.lawlink. nsw.gov.au/divserv/ds_capacity_tool.html (accessed Jul 2014).

22 American Bar Association Commission on Law and Aging, American Psychological Association, National College of Probate Judges. Judicial determination of capacity of older adults in guardianship proceedings: a handbook for judges. Washington, DC: ABA and APA, 2006. www.apa.org/ $\mathrm{pi} /$ aging/resources/guides/judges-diminished.pdf (accessed Jul 2014).

23 Banks v Goodfellow (1870) LR 5 QB 549.

24 O'Neill N, Peisah C. Capacity and the law. Sydney: Sydney University Press, 2011. 